\title{
MAKERSPACES IN LIBRARIES: Technology as Catalyst for Better Learning, Better Teaching
}

\author{
Patrick Tod Colegrove ${ }^{1}$ \\ ${ }^{1}$ PhD in Engineering. Professor, University Libraries, University of Nevada, Reno, Nevada, USA. \\ Email: pcolegrove@unr.edu
}

Received date: September 5, 2016 Accepted date: December 10, 2016

How to cite this article: P. Tod-Colegrove, "Makerspaces in Libraries: Technology as Catalyst for Better Learning, Better Teaching", Ingeniería Solidaría, vol. 13, n. ${ }^{\circ}$ 21, pp. 19-26, January 2017. doi: http://dx.doi.org/10.16925/in.v13i21.1724

\begin{abstract}
Introduction: Across disciplines, the practice of education continues to evolve. Supporting organizations such as the library are responding by reworking existing practices while developing new ones. With roots grounded deeply in constructivist learning theory, the emerging practice of makerspaces in libraries is proving an effective step in that evolution. The article was written in the year 2016 at the University of Nevada, Reno. Methodology: Examples of associated active learning activity at one such library - an early adopter and first mover among academic libraries in adopting and integrating makerspace in libraries - are presented. Results and Conclusions: The product of leveraging technology as catalyst for active learning and engagement within and beyond the physical commons of the library, a blending of formal and informal learning, leading to increased innovation, entrepreneurship and collaboration across disciplinary and organizational boundaries, appears a natural result.
\end{abstract}

Keywords: active learning, emerging technology, future of libraries, innovation, makerspace. 


\section{MAKERSPACES EN LAS BIBLIOTECAS: LA}

\section{TECNOLOGÍA COMO CATALIZADOR PARA UN MEJOR}

\section{APRENDIZAJE Y UNA MEJOR ENSEÑANZA}

Resumen. Introducción: en todas las disciplinas, la práctica de la educación continúa evolucionando. Las organizaciones de apoyo, como la biblioteca, están respondiendo mediante el replanteamiento de las prácticas existentes y el desarrollo de otras nuevas. Con raíces profundamente arraigadas en la teoría del aprendizaje constructivista, la práctica emergente de los espacios creativos o makerspaces en las bibliotecas está demostrando ser un avance efectivo en esa evolución. Este artículo fue escrito en el 2016 en la Universidad de Nevada. Metodología: se presentan ejemplos de actividades de aprendizaje activo y asociado en una de estas bibliotecas, una de las bibliotecas académicas pioneras y promotoras de makerspaces en sus locaciones. Resultados y conclusiones: emergen como resultado natural, el producto de la tecnología de apalancamiento como catalizador del aprendizaje activo y el compromiso dentro y fuera de los confines físicos de la biblioteca; la combinación del aprendizaje formal e informal que conduce al aumento en la innovación, el emprendimiento y la colaboración a través de fronteras disciplinarias y organizativas.

Palabras clave: aprendizaje activo, tecnología emergente, futuro de las bibliotecas, innovación, makerspace.

\section{MAKERSPACES NAS BIBLIOTECAS: A TECNOLOGIA COMO CATALIZADOR PARA UMA MELHOR APRENDIZAGEM E UM MELHOR ENSINO}

Resumo. Introdução: em todas as disciplinas, a prática da educação continua evoluindo. As organizações de apoio, como a biblioteca, estão respondendo mediante o replanejamento das práticas existentes e do desenvolvimento de outras novas. Com raízes profundamente arraigadas na teoria da aprendizagem construtivista, a prática emergente dos espaços criativos ou makerspaces nas bibliotecas está demonstrando ser um progresso efetivo nessa evolução. Este artigo foi escrito em 2016 na Universidad de Nevada. Metodologia: apresentam-se exemplos de atividades de aprendizagem ativa e associada numa dessas bibliotecas, a qual é uma das pioneiras e promotoras de makerspaces nas bibliotecas. Resultados e conclusões: emergem, como resultado natural, o produto da tecnologia de alavancagem como catalizador da aprendizagem ativa e do compromisso dentro e fora dos espaços físicos da biblioteca; a combinação da aprendizagem formal e da informal que conduz ao aumento na inovação, do empreendimento e da colaboração por meio de fronteiras disciplinares e organizacionais.

Palavras-chave: aprendizagem ativa, tecnologia emergente, futuro das bibliotecas, inovação, makerspace. 


\section{Introduction}

Informal learning happens anytime, anywhere. Increasingly, the learning associated with formal academic programs is taking place outside classrooms, driving an ongoing transformation across the educational landscape [1]. As educational practice continues to move toward a model more appropriate for the post-Industrial Age [2], librarians and the commons of library are becoming ever more integral to the learning and teaching lives of the communities they support, blending traditional roles of content provision with support of active and collaborative learning. Makerspaces in libraries is a relatively recent phenomenon - a natural adjunct that crosses disciplinary boundaries of educational innovation, integration of formal and informal learning, Science, Technology, Engineering, and Math (sTEM) outreach and engagement. Combined with the Arts (STEAM), the resulting overlapping confluence of interests can drive innovation and entrepreneurship across the supported communities.

This paper presents examples of activity from one of the first movers of the makerspaces in libraries movement, the first academic library in the United States to offer 3D printing and scanning as a library service available to all [3]. In addition to presenting examples of both self-directed and collaborative learning, specific actions are detailed that have enabled the organization to more closely realize institutional and administrative goals. Rather than merely supporting learning by rote, in a makerspace learning is driven directly by curiosity and engagement on part of the end-user, with a resulting integration of formal and informal contexts across learning styles. In such an active learning environment, the role of librarians as catalyst and connectors becomes central, reflecting a view of learning expressed by Plutarch nearly two thousand years ago: "the mind is not a vessel to be filled, but a fire to be kindled" [4]. The pages following will offer insight into the changing roles of librarians and potential roles of the library across the educational enterprise in kindling and nurturing the flames of Plutarch's fire in the minds of learners of today.

\section{Methodology}

At its heart, the fundamental philosophy connecting makerspace activity with learning is constructivist learning theory. Halverson \& Sheridan [5] frame the role of makerspaces in education as simply a natural evolution of constructivist thought, from Dewey and Piaget through Seymour Papert's Constructionism. Ellis \& Philips [1] further note that recent decades have witnessed the practice of education evolving away from the traditional teacher-focused "transmission-style of teaching and learning, which were teacher focused, to a variety of constructivist perspectives which focus on how the learner constructs meaning through active and social learning and personal context" [emphasis added]. Beyond traditional roles of selecting and providing access to shared resources, libraries are increasingly moving toward playing more central roles in the teaching and learning lives of their communities.

Whether in support of active learning on the part of the student, or co-curricular development with teaching faculty, the development and support of the constructivist learning environment is key to effective institutional support of learning. Jonassen [6] articulates design principles and lays the groundwork; Stripling \& Hughes-Hassel [7] detail the beginnings of more widespread library adoption and support in the introduction of the more formalized concept of inquiry-based learning and the support of collaborative learning communities. In addition to a thorough backgrounding, Woodard [8] frames library support as a function of teaching information literacy skills -importantly, recognizing that technology can serve as catalyst triggering learning, changed teaching practices, and different roles for educators themselves. Tracing the natural evolution, Levy \& Roberts [9] recognize the changing roles of librarians in the practice of education, and document the emerging roles of librarians as educators and active partners in educational development.

The introduction and rapid adoption of the Framework for $21^{\text {st }}$ Century Learning [10] consolidated the approach and growing support for constructivist and/or problem-based learning approaches by libraries. With mastery of key subjects, such as reading and languages, arts, mathematics, and sciences at the core, the framework was designed with a vision of ensuring "student success in a world where change is constant and learning never stops." With interdisciplinary themes woven throughout, the framework identifies overarching support for "Learning and Innovation Skills," "Information, Media, and Technology skills," with "Life and Career Skills." Recognizing the role of 
librarians as vital partners and agents in support of $21^{\text {st }}$ century learners, Kuhlthau [11] recognizes the active hybridization of roles in support of inquiry-based learning with constructivist models of learning. Booth [12] established the foundation for the development of library instructors around deeply constructivist roots, providing a legitimate platform for the use of technologies, emerging and otherwise, into standard library practice, recognizing with Beagle [13] constructivist learning support as emergent in the information commons of the academic library.

With growing library adoption and support of constructivist learning, branded variously as "creative collaboration," "cultivating curiosity," or " $21^{\text {st }}$ century learning," such active learning behavior began to be recognized as "maker" activity. Over the same timeframe, associated makerspaces in libraries began to proliferate to meet the needs of "fundamentally experiential learners, actively engaged and solving problems, posing questions, and making decisions" [14]. Resources including Beetham \& Sharpe's [15] began to arrive, establishing the connections between formal pedagogy and the types of $21^{\text {st }}$ century learning being adopted and supported in libraries worldwide. Indeed, a global survey of libraries conducted near the end of 2013 found that fully seventy-eight percent of respondents either already provide makerspace or were planning to do so in the near future [emphasis added] [16].

Grounded in learning theory, appropriately framed in terms of $21^{\text {st }}$ century learning, and with growing adoption worldwide, there is growing recognition that makerspace in libraries offers an environment in which formal and informal learning can blend naturally. Driven by self-interest, spontaneous and collaborative engagement in makerspace activity can enable members of communities of practice to develop and hone competencies associated with formal academic programs.

\section{Results: Active Learning in Practice}

Across education, it is widely accepted that much of the learning by students enrolled in academic programs takes place outside of formal classrooms. Even with recent innovations such as flipped classrooms, it is when the learner actively engages with the materials to be learned, whether or not as "home" work, that learning happens. In practice, for a majority of students, significant amounts of learning takes place in a collaborative fashion as students actively engage with one another around the topic of study. Whether school library for K-12, an academic library in higher education, or public library where boundaries cross, the library is one of a small number of places ideal for the activity. Rather than the formality of classrooms, or the informality and relative solitude of home, the library is a "third place;" [17] intrinsically neutral, and dedicated to values of equal access to all, it is a place where learners gather.

Technology has always been a catalyst for learning in the library. Consider the book itself, or codex, a technology that only came into existence in the fifteenth century; prior, relevant library technology included papyrus scrolls or even stone tablets. And yet arguably, the broader access to that technology enabled by the library has, over the course of time, transformed society. In recent decades, that technology has expanded to include photocopier machines, Information and Communications Technology (ICT) such as personal computers and laser printers. In a makerspace technology typically expands further, and might range from pipe cleaners and glue guns to $3 \mathrm{D}$ printers and laser cutters; the increased access to such technology, by means of the library, continues to impact.

\section{Active Learning}

In any examination of library technology that directly supports teaching and learning across disciplines, simple things such as collaborative study areas are too easily overlooked; conversation itself is a powerful tool in support of collaborative learning. The library can encourage such informal learning behavior simply by leveraging the arrangement of furniture and ready availability of resources. In the case of the DeLaMare Science \& Engineering Library, non-traditional library technology introduced included whiteboards and markers. In combination with an active encouragement of conversation, and availability of study tables that also lended themselves to use as whiteboard surfaces, ad hoc study groups began to form throughout the library. In 2010 an initial pilot of two rolling whiteboards with a writeable surface four feet in height and eight feet in width was quickly expanded to a total of six. With heavy use, the library continued to expand the availability of ad hoc collaboration areas throughout the library by painting 
entire walls with whiteboard paint (Figure 1) [18]. By 2013 the library had over 20,000 square feet of whiteboard writeable space - throughout a space that is roughly 22,500 square feet in total- and there are times in the semester when that is still not enough. The library is alive with formal and informal learning behavior; although predominantly student-driven, faculty regularly leverage the space to hold office hours and review sessions with ready access to space to encourage students to engage directly in moderated problem solving.

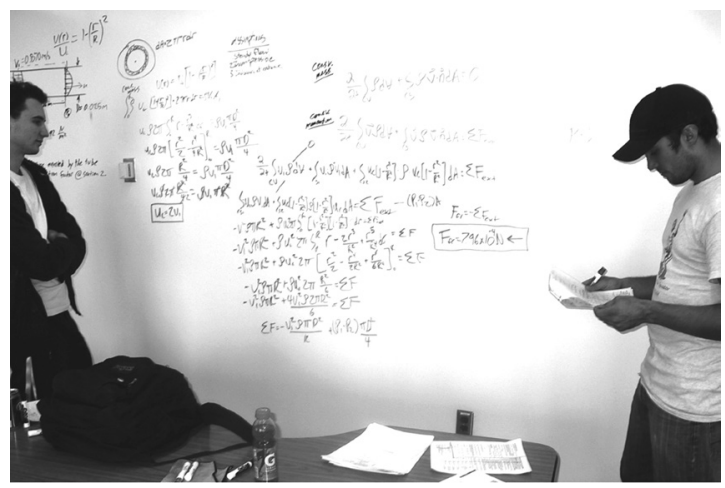

Figure 1. Ready availability of writeable "whiteboard" surfaces throughout the library seems to greatly improve the formation of ad hoc collaboration between students attempting to problem solve and learn formal academic course material.

Source: Compiled by the authors

Driven by requests from the communities supported, novel resources and services added by the library in support of active learning range from $3 \mathrm{D}$ printers and scanners, a wide range of lendable technology, laser and vinyl cutters, and even a printed circuit board mill: each is information technology that serves to catalyze both self-directed and collaborative active learning. As an example, at the University of Nevada, Reno, all incoming freshman students enrolled in Engineering are required to pass the ENG 100 introductory course. In that course, students are introduced to basic concepts of engineering by means of group projects that include the design and construction of robotic hovercraft piloted and controlled by LEGO Mindstorms technology and box fans, powered by a hydrogen fuel cell. In support, the library provisions LEGO
Mindstorms robotics toolkits that are available for checkout. Custom parts are regularly designed and $3 \mathrm{D}$ printed for new designs, and the laser cutter is regularly busy cutting shapes from Styrofoam and other materials for assembly. Figure 2 shows a snapshot of one such group actively constructing a prototype within the spaces of the library, with ready access to supporting technology.

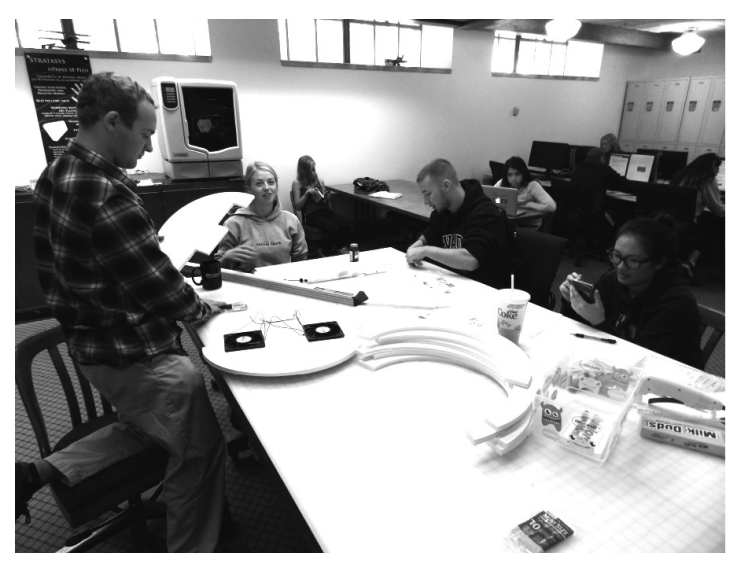

Figure 2. Students regularly utilize the spaces and rapid prototyping services of the library to collaboratively develop projects. In this case a team of ENG 100 students are actively engaged in assembling the pieces of their custom robotic hovercraft design on the main floor of the library. Note the structural pieces recently cut from a sheet of Styrofoam by means of laser cutter technology provisioned by the library. Source: Compiled by the authors

Similarly, for advanced courses such as Statics, the laser cutter is regularly used by students to precision cut designs from balsa wood (Figure 3), prior to assembly and testing of designs. In a real sense, the laser cutter is simply another type of "printer," producing the precise shapes by cutting away the excess material in a subtractive process. The rationale for implementing such a shared service or resource in the library is simple: libraries are fundamentally about sharing and supporting, sometimes expensive technology, to the benefit of all. The ability to rapidly prototype and test ideas is on the critical path to learning and the creation of new knowledge, and the library is a natural hub. 


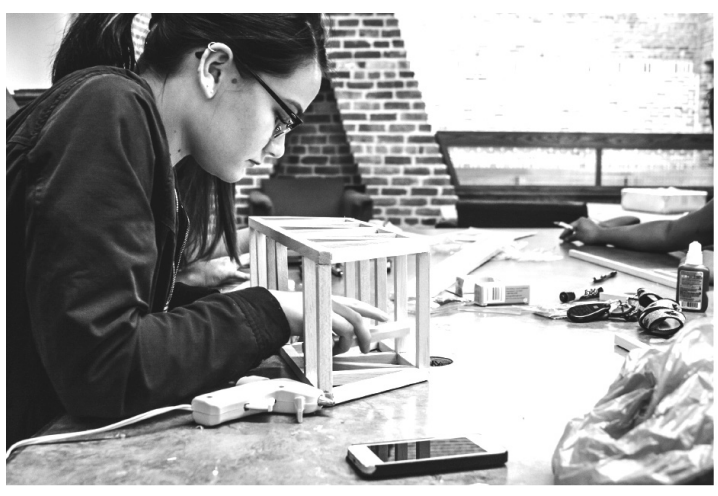

Figure 3. A team of engineering students assemble a realworld model from their custom design of a truss bridge as part of a classroom assignment. Built of balsa wood structural members precision cut to design specification on a laser cutter, successful designs can sustain static loads far in excess of the 100-kilogram requirement.

Source: Nick Crowl

\section{Innovation and Entrepreneurship}

Learning and engagement within the library makerspace seems to lead naturally to innovation and entrepreneurship. Due to the ready access to rapid prototyping equipment, combined with the creative abrasion and intellectual stimulation that becomes largely unavoidable in such an active hub, it is perhaps not surprising. One such example is the Hummingdoc [19] -a stethoscope adapter for the microphone widely available on a range of smartphone headsets. Combined with a similarly developed smartphone app, it can enable the user to listen to and analyze heart and lung sounds. Initially conceived to enable expectant parents to hear their as yet unborn child's heartbeat without needing to go to the doctor's office, the product was prototyped with the $3 \mathrm{D}$ printing services of the library and members of the supporting community. Within months, the product had gone from proof-of-concept to production runs of hundreds at a time. The product went on to be the nucleus of a separately created limited liability company, Hummingdoc LLC, with product actively being sold and delivered.

Another example of a product conceived and prototyped with support of the library's makerspace equipment and services is the InfinitByte flash drive [20]. Designed around the use of microSD cards, the waterproof and ruggedized drive holds two cards yielding a capacity of up to four terabytes operating at speeds of up to $5 \mathrm{Gbps}$. Its inventor, a retired military Blackhawk helicopter pilot instructor, spent a substantial amount of time working with students at the University to develop the part designs to exacting specifications using $3 \mathrm{D}$ modeling software in the library. After an initial Kickstarter crowfunding campaign failed to reach needed funding goals, its designer, and the students he had been working with, learned critical business lessons. In response to feedback from the campaign as to pricing, he reworked his supply manufacturing chain and was able to reduce the anticipated final cost by more than half, to something on the order of a few tens of dollars; a second Kickstarter campaign is currently under development, with an anticipated near-term launch.

Beyond directly enabling innovation and entrepreneurship, the benefit of learning on the part of the students involved in such cases cannot be overstated -the sort of learning that can at best be presented as theoretical in the classroom environment. Authentic experiential learning, driven by real-world considerations, has repeatedly translated into direct benefit for those involved; going beyond knowledge creation, providing skills and experience that are valued in academia as well as in private industry.

\section{Engagement Leading to Outreach}

The lending technology collections of the library are proving to be a key ingredient in outreach and engagement. In addition to K-12 and academic liaison outreach, the availability of a continuum of technology in support of self-directed learning is proving watershed. In addition to enabling deeply personal interest-driven learning, numerous student organizations at the University regularly utilize the borrowed technology as part of STEM outreach activities with local schools and museums, greatly exceeding the impact the library could have alone.

Further, consider a crossover example that combines curiosity, building to full engagement, disciplinary, and career choices, leading directly to entrepreneurship. A student, self-described as "flailing and uncertain," and without having declared a major by the end of his sophomore year, borrowed an entry-level micro-programmable from the library. After exhausting interest with the MakeyMakey kit, [21] with its ability to control web-based 
games by means of simple connections, he returned and checked out the next step: a Sparkfun Arduino Inventor kit [22] with associated how-to documentation. A few weeks later the student renewed the kit, with its wealth of electronic bits and pieces, stepping up to check out a Raspberry Pi, assorted shields, and a soldering iron kit. The following semester, the author heard directly from a faculty member of the robotics lab on campus about a new student who had "mad skills" -he could program, solder, prototype...- it was in fact the very same student. Note that the skills that were most valued by the Engineering faculty member were not those that were being taught in the formal classroom, but those that had been learned by the student on his own with access to appropriate and supporting resources through the library. Figure 4 is a picture of the student in the robotics lab, where he worked for the remainder of his undergraduate term, proudly showing the forearm of a prototype android he had constructed. Even the 3D printed white ABS plastic structure of the forearm and digits was a direct product of engagement with library resources, as he had printed the pieces by means of the library's $3 \mathrm{D}$ printing and scanning service.

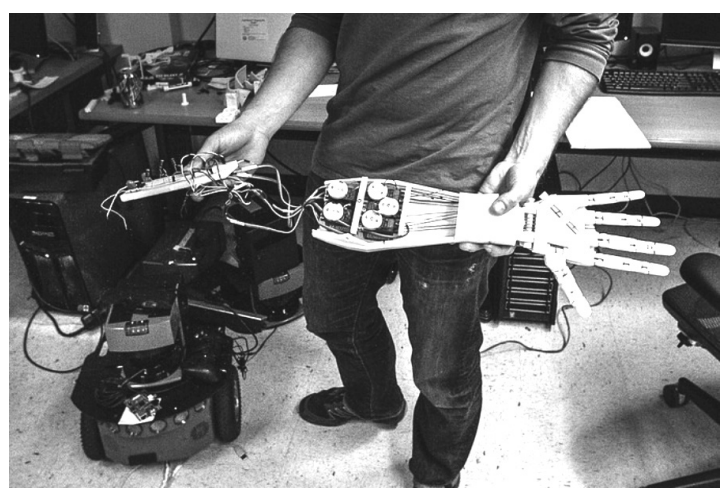

Figure 4. Prototype android arm, controlled by logic assembled on the breadboard circuit in the student's right hand. Note that the structure and enclosure of the forearm and digits is composed of parts fabricated by means of the library's 3D printing service. Source: Nick Crowl

Although one might expect an associated entrepreneurial effort to be associated with robotics, upon graduation this past year, the student joined forces with a fellow engineer to create the online company dringo.org [23] to connect students with businesses by means of crowdsourcing the search.

\section{Conclusion}

This paper has touched on only a few of the many examples witnessed recently in the library, reimagined to not only allow for, but encourage active learning. The examples presented can only hint at the tantalizing possibilities: full engagement with the active learning environment of makerspaces in libraries can be transformative. Motivated by curiosity and self-interest, and supported by the library resources, acquisition of $21^{\text {st }}$ century skills ranging from information, media, and technology skills to innovation, life, and career skills are a natural outcome of engagement with the resources of the library. In addition to blending traditional roles of content provision with support of active and collaborative learning, opportunities for engagement and creative abrasion across STEAM disciplines are driving innovation and entrepreneurship across the community.

\section{Acknowledgements}

The author wishes to thank the organizers of the UNESCO-UNIR ICT \& Education Latam Congress 2016 generally, and General \& Scientific Chair Daniel Burgos of the Universidad Internacional de la Rioja for convening the conversation from which this paper evolved. Further, thanks are extended to the many colleagues and stakeholders of the library across the Colleges of Science, Engineering, and Libraries at the University of Nevada, Reno, without whose support, this ongoing work would not be possible. The support of the International Baccalaureate program during the initial development of the literature review is also gratefully acknowledged.

\section{References}

[1] J. Ellis \& A. Phillips, "Re-defining the service experience: forging collaboration between librarians and student" Library Management, vol. 34, no. 8-9, pp. 603-618, 2013. Available: http://dx.doi.org/10.1108/ LM-10-2012-0070

[2] D. Bell, The Coming of Post-Industrial Society, New York, USA: Harper Colophon Books, 1973, p. 616. 
[3] Y. U. Chin, "Nevada Library Offers 3D Printing Across the Board." Library Journal, August 7, 2012. Available: http://lj.libraryjournal.com/2012/08/academic-libraries/u-nevada-library-offers-3d-printing-across-the-board/

[4] A. Jenkins, M. Healey, \& R., Zetter, Linking teaching and research in disciplines and departments. York, Uk: The Higher Education Academy, 2007, p. 96. Available: https://www.heacademy.ac.uk/system/ files/186_linkingteachingandresearch_april07.pdf

[5] E. R. Halverson \& K. M. Sheridan, “The Maker Movement in Education." Harvard Educational Review, vol. 84, pp. 495-504, 2014. Available: http://dx.doi. org/10.17763/haer.84.4.34j1g68140382063

[6] D. H. Jonassen, "Designing constructivist learning environments" in Instructional-Design Theories and Models: A New Paradigm of Instructional Theory, volume 2. C. M. Reigeluth, Ed.. Mahwah, NJ: Lawrence Erlbaum Associates, 1999, pp. 215-240.

[7] B. K. Stripling \& S. Hughes-Hassell (Eds.), Curriculum Connections through the Library, Principles and practice series. Westport, CT: Libraries Unlimited, 2003, p. 256.

[8] B. S. Woodard, "Technology and the constructivist learning environment: Implications for teaching information literacy skills." Research Strategies, vol. 19, pp. 181-192, 2003. Available: http://www.sciencedirect.com/science/article/pii/S0734331005000029

[9] P. Levy \& S. Roberts, Developing the New Learning Environment: The Changing Role of the Academic Librarian. London, uk: Facet Publishing, 2005, p. 256.

[10] Framework for $21^{\text {st }}$ Century Learning. Washington, D.C.: Partnership for $21^{\text {st }}$ Century Learning. Available: http://www.p21.org/our-work/p21-framework

[11] C. C. Kuhlthau, "Guided Inquiry: School Libraries in the 21st Century," School Libraries Worldwide, vol. 16, pp. 17-28, 2010. Available: http://citeseerx.ist. psu.edu/viewdoc/summary?doi=10.1.1.721.8981

[12] C. Booth, Reflective Teaching, Effective Learning: Instructional Literacy for Library Educators. Chicago, IL: American Library Association, 2011, p. 208.
[13] D. Beagle, “The Emergent Information Commons: Philosophy, Models, and 21st Century Learning Paradigms." Journal of Library Administration, vol. 52, no. 6-7, pp. 518-537, 2012. Available: http://www. tandfonline.com/doi/abs/10.1080/01930826.2012.7 07951

[14] P. T. Colegrove, "Makerspaces in Libraries" in Encyclopedia of Library and Information Sciences. Abingdon, UK: Taylor \& Francis Group, 2016 (in press).

[15] H. Beetham \& R. Sharpe (Eds.), Rethinking Pedagogy for a Digital Age: Designing for 21st Century Learning, $2^{\text {nd }}$ ed. New York: Routledge, 2013, p. 352.

[16] J. J. Burke, Makerspaces: a practical guide for librarians. Lanham: Rowman \& Littlefield, 2014, pp. 165 171.

[17] R. Oldenburg, The great good place: Café, coffee shops, community centers, beauty parlors, general stores, bars, hangouts, and how they get you through the day. New York: Paragon House Publishers, 1991, p. 338 .

[18] P. T. Colegrove, "Rediscovering Relevance for the Science \& Engineering Library" in Brick and Click Libraries Symposium Proceedings, $12^{\text {th }}$, Maryville, Missouri, Oct. 26, 2012, pp. 57-65. Available: http:// eric.ed.gov/?id=ED537605

[19] Hummingdoc. Reno, Nv: hummingdoc.com. Available: http://www.hummingdoc.com/

[20] J. Horsey, "Infinitbyte: Fast, Waterproof and Rugged Highest Capacity Flash Drive," Geeky-gadgets.com, April 2, 2015. Available: http://www.geeky-gadgets. com/infinitbyte-fast-waterproof-and-rugged-highest-capacity-flash-drive-02-04-2015/

[21] "Makey Makey" Joylabz.com. Available: http:// makeymakey.com/

[22] "Sparkfun Inventor's Kit for Arduino", Sparkfun. com. Available: https://www.sparkfun.com/products/retired/11227

[23] “Dringo beta." Reno, NV: dringo.org. Available: https:// dringo.io/ 